\title{
Da literatura: ensaio, performance e fracasso
}

\author{
Suelen Ariane Campiolo Trevizan*
}

\begin{abstract}
Resumo
Neste ensaio, a crítica critica a si mesma, assume-se como metacrítica. Quando o ditador, personagem conceitual de Maurice Blanchot, exige que o crítico explicite qual é sua importância na contemporaneidade, este se retira para primeiro esclarecer a própria concepção de literatura. Nessa investigação, passa por pensadores do exterior, como o já citado Blanchot, além de Michel Foucault, Gilles Deleuze e outros, até chegar a Juliano Garcia Pessanha, autor brasileiro que herda e reelabora tal tradição. Contaminada pelo tom satírico de Luciano de Samósata, proponho um entendimento de literatura como ensaio e performance. O crítico, por fim, compreende o teor artístico e o gesto político da atuação dele.
\end{abstract}

Palavras-chave: Literatura. Crítica literária. Pensamento do exterior. Ensaio. Performance.

\section{Of literature: essay, performance and failure}

\begin{abstract}
In this essay, criticism criticizes itself, it becomes metacriticism. When the dictator, the Maurice Blanchot's conceptual character, requires the critic to explain what is its importance nowadays, he retires to first clarify his own conception of literature. In this investigation, he passes through some thinkers of the outside, such as Blanchot, as well as Michel Foucault, Gilles Deleuze and others, even Juliano Garcia Pessanha, a Brazilian author who inherits and re-elaborates that tradition. Contaminated by Lucian of Samosata's satirical tone of, I propose an understanding of literature as essay and performance. The critics, finally, understands the artistic content and the political gesture of his performance.
\end{abstract}

Keywords: Literature. Literary criticism. Thought from outside. Essay. Performance.

Recebido: 29/01/2019

Aceito: 03/05/2019

* Universidade Federal de Minas Gerais (UFMG). Doutoranda em Teoria Literária e Literatura Comparada do programa de Pós-Graduação em Estudos Literários. Bolsista CAPES. 


\section{Preâmbulo}

CRÍTICO - Deleuze e Guattari escreveram que...

LEITOR - Ih, já vai começar citando Deleuze e Guattari? Conheço bem o seu tipo... Fui!

CRÍTICO - Ei, não vá! Este trecho é até poético, você vai gostar. Tsc, tsc. É por isso que o povo se deixa manipular tão facilmente, virou as costas justo para quem poderia salvá-lo da ignorância. Ninguém mais dá importância aos acadêmicos. Eu estou aqui o tempo todo no meu gabinete, sapientíssimo, e ninguém vem me consultar, ninguém! O povo que se dane também! Pois digo só para mim mesmo, que sou merecedor destas pérolas: Deleuze e Guattari escreveram que o homem, por não conseguir lidar com o caos, abriga-se sob o guarda-sol das opiniões, mas vem o artista e abre um rasgo nessa cobertura, fazendo-nos lembrar a existência do caos. Maldosamente, dizem que os críticos e os falsos artistas são um bando de papagaios a preencher a fenda com mais discursos apaziguadores, mais opiniões. Só que eu não me identifico com essa parte. Eu não. Sou um leal servidor da arte, vivo para exaltá-la, para garantir que o artista tenha recursos para comprar mais navalhas quando a sua perder o fio. Eis que finalmente se dirigem a mim... Lá vem uma figura de autoridade prestigiar meu conhecimento.

DITADOR - TEM QUE ACABAR COM ISSO AÍ. O SENHOR FICA SÓ MAMANDO NAS TETAS NO GOVERNO, NÃO FAZ NADA, NEM PARA PROCRIADOR SERVE. E TEM MAIS: SEU ALUNO TUITOU QUE O SENHOR É UM MARGINAL VERMELHO.

CRÍTICO - Não, senhor. Não há nada de marxista aqui, é apenas pensamento do exterior.

DITADOR - GLOBALISMO, DIALÉTICA GAY, DIREITOS HUMANOS... TEM QUE ACABAR COM TUDO ISSO AÍ QUE NÃO SERVE PARA NADA.

CRÍTICO - Mas eu tenho utilidade, juro! Eu escrevo sobre literatura contemporânea.

DITADOR - LEI ROUANET PARA VAGABUNDO FAZER IDEOLOGIA DE GÊNERO.

CRÍTICO - Me deixe explicar, senhor. Literatura é... É... O senhor pode me dar um dia para preparar minha resposta? Preciso consultar alguns colegas no Hades.

DITADOR - COM UMA CONDIÇÃO: CONVENÇA O NOBRE C. U. A VOLTAR DO HADES. O POVO PRECISA DE HERÓIS ${ }^{1}$ COMO ELE.

\section{Nota explicativa 1}

O diálogo satírico com que abri este ensaio é uma homenagem a Luciano de Samósata, "um autêntico cão, tanto mais pavoroso, quanto a sua mordedura é pela calada e morde enquanto ri." (SAMÓSATA, 2012, p. 117). Esse retórico viveu no Império Romano no século II e, apesar de sua língua materna provavelmente ter sido o aramaico, escrevia em grego. São conhecidos 82 textos de sua autoria, um volume considerável que indica a popularidade de sua obra, apesar de (ou por causa de) atacar várias figuras célebres de seu tempo e da história. A partir do diálogo filosófico, gênero consagrado por Platão, Luciano inseria narrativas cômicas, resultando em uma forma híbrida bastante inovadora para seu contexto de produção. Por articular filosofia e literatura, história e ficção, retórica e linguagem vulgar, esse estilo de escrita muito influenciou a literatura moderna e, sobretudo, a contemporânea, ao se apresentar como algo "que se realiza e se dissolve no entre" - formulação que, no decorrer deste ensaio, ficará mais clara.

Flora Süssekind chama essa tendência na contemporaneidade de coralidades, devido à semelhança com o antigo coro teatral, no quesito de multiplicidade de vozes e sobreposição de registros. Observamos aí mais um ponto de aproximação com práticas artísticas da Antiguidade, um exemplo 
da “co-presença de temporalidades heterogêneas" (RANCIÈRE, 2005, p. 37), própria do atual regime estético, que substitui uma noção progressista de história por arranjos mais horizontalizados dos registros. Ao descrever esses OVNIs (objetos textuais não identificados), Süssekind destaca sua importância para a própria definição de literatura na atualidade:

Coralidades nas quais se observa, igualmente, um tensionamento propositado de gêneros, repertório e categorias basilares à inclusão textual em terreno reconhecidamente literário, fazendo dessas encruzilhadas meio desfocadas de falas e ruídos uma forma de interrogação simultânea tanto da hora histórica, quanto do campo mesmo da literatura. (SÜSSEKIND, 2013, [s.n].).

Em suma, formações como essas não se acomodam com a criação de novas categorias de gênero, mas exigem uma redefinição de todo o campo literário. Assim, as fronteiras deste tornam-se esponjosas, não protegem coisa alguma, aliás, nem se sabe mais o que deveriam guardar. Cenário propício à contaminação, imagem muito presente no discurso sobre o contemporâneo e que, inclusive, também fora empregada por Luciano de Samósata: a mordida do cão raivoso transmite a loucura, no bom e no mau sentido. ${ }^{2} \mathrm{O}$ lado negativo é a "doença", a perda da sensação de autocontrole, a dissolução da identidade; o positivo, quando se aceita essa instabilidade como condição perpétua da vida, é o aguçamento do senso crítico, pois se adquire o olhar estrangeiro sobre si mesmo, de modo a rever práticas antes tidas como lógicas ou naturais. Esse contágio pelo diferente, o reconhecimento da própria incompletude, numa aproximação com a performatividade, é o que possibilita uma comunidade (PEDROSA et al., 2018, p. 145). Comunidade não de iguais, mas aberta e heterogênea, logo, plurivocal - coral.

No regime estético contemporâneo, o diálogo com várias áreas do saber interfere não só nos temas tratados pela literatura como na sua linguagem. A presença de jargões e sintaxe próprios da ciência, da filosofia, dos meios de comunicação etc. pode ser pontual ou até predominante, a ponto de o Prêmio Nobel de Literatura, atento a essa tendência, ter prestigiado, em anos recentes, a jornalista Svetlana Alexijevich e o músico Bob Dylan. Até mesmo a palavra escrita vai cedendo espaço para outras linguagens, novos suportes são incorporados, e assim se tem cada vez menos certeza do que seria uma obra literária, que vai gradualmente deixando de marcar sua diferença em relação a expressões não artísticas.

Nos termos de Deleuze e Guattari (2017), poderíamos falar em um movimento de desterritorialização, o que para eles não representa uma ameaça à literatura; pelo contrário, é o que fomenta a criação artística. Obtém-se algo inédito dessa abertura, novos cosmos - ou "caosmos", segundo o neologismo criado por esses pensadores e empregado repetidamente em sua obra. Em outras palavras, quando um território se abre, a contaminação do exterior pode resultar na extinção daquele arranjo antigo, mas outros territórios se constituem a partir dali. A abertura não leva, necessariamente, a uma queda no caos, mas reforça a percepção de que o cosmo é dinâmico. Para nosso crítico, porém, essa é uma má notícia, pois ele precisa se reportar ao ditador, que exige respostas exatas e definitivas.

2 Neste excerto Luciano explicita o caráter contagioso de sua sátira: "Mas não fiques admirado, pois bem sabes que aqueles que são mordidos por cães raivosos não são os únicos a ficarem raivosos, pois se estes, na sua fúria, fizerem a outros o mesmo [que lhe fizeram a si], também esses outros ficarão fora de si. É que existe nesse mal algo que se transmite juntamente com a mordedura, pelo que a doença se propaga e se gera uma grande série de loucuras em cadeia." (SAMÓSATA, 2013, p. 102). 


\section{No Hades}

Tal qual Orfeu, o crítico desceu ao Hades em busca daquilo que sempre lhe escaparia, sua Eurídice, a Literatura. Essa bela metáfora, porém, não lhe renderá pontos no Lattes, pois o acadêmico reconhece que a roubou de Maurice Blanchot. Aliás, por coincidência, o ensaísta francês foi o primeiro morto que o visitante identificou, bem à vontade ali no círculo da negatividade. No centro do pequeno grupo, que exalava um cheiro de café e tabaco, havia um homem todo vestido de branco com barba e cabelos longos. Era o Zaratustra de Nietzsche. O guru enfim encontrara quem o ouvisse, e todos discípulos de peso, mas era uma gloria post mortem - não há outro tipo de reconhecimento para o escritor, infelizmente. Além de Blanchot, lá estavam Fernando Pessoa, Martin Heidegger, Witold Gombrowicz, Nikos Kazantzákis, Georges Bataille, o jovem Michel Foucault, Gilles Deleuze, Jacques Lacan, Jacques Derrida e alguns outros. Curioso que não houvesse nenhuma mulher, decerto ouviram certos comentários do bigodudo sobre elas.

Embora Zaratustra estivesse posicionado no centro, lugar de destaque, ele preferia ouvir a falar e, acima de tudo, preferia dançar. Quando o crítico se aproximou discreto, sem propriamente entrar no círculo, era a vez de Gombrowicz entreter a plateia. Mal contendo o riso, o locutor contava a bizarra história do escritor que buscava uma unidade na sua escrita.

GOMBROWICZ - Psiu, silêncio, algo de misterioso está acontecendo - temos a nossa frente um autor cinquentão, ajoelhado diante do altar da arte, criando, pensando em sua obra-prima, em sua harmonia, precisão, espírito e superação; e temos também um especialista que se revela um profundo conhecedor da obra do autor, depois do que a obra é revelada ao mundo e chega às mãos do leitor [- nesse momento o crítico se aplumou, orgulhoso da importância de seu trabalho]. E tudo aquilo que começara com grandes sacrifícios e total dedicação será recebido em partes, entre telefonemas e costeletas de porco (GOMBROWICZ, 2006, p. 101).

DISCÍPULOS DE ZARATUSTRA - Viva a costeleta de porco! Viva!

Então o crítico murchou, não era ele que deveria ser aclamado? Que bando de malucos!

Aprendiz da transvaloração nietzschiana, o escritor polonês defendia e praticava o fragmentário, o cômico e o escatológico. Mesmo entre amigos, colocava um bumbum dos mais incômodos em todos e ria na fuça deles. Outro que era obcecado por escatologia, Artaud, não achou certo jogar toda a responsabilidade do fracasso sobre o leitor nem sobre as costeletas de porco. Para ele, a culpa era do bom-mocismo burguês a que o artista se submetia para atrair audiência. $\mathrm{O}$ ator-poeta iniciou sua resposta numa murmuração de palavras desconhecidas, até que se levantou irritado e, movendo-se frenético de um lado para o outro, despejou sobre todos:
ARTAUD -
O DEVER
do escritor, do poeta,
não é de ir se esconder num livro, num texto, numa revista de onde ele nunca mais sairá,
mas ao contrário
de sair
para fora

para agitar
para atacar
o espírito público
senão
para que ele serve? (ARTAUD, 2017, p. 167-168).

DISCÍPULOS DE ZARATUSTRA - Abaixo o livro! Viva a costeleta de porco (para viagem)!

Prontamente se levantou um acadêmico para explicar a anarquia criada pelos escritores - até no mundo dos mortos queriam explicar o inexplicável -, e ninguém menos do que Deleuze. 
DELEUZE - A literatura está antes do lado do informe, ou do inacabamento, como Gombrowicz o disse e fez (DELEUZE, 1997, p. 11). Estes são os três aspectos perpetuamente em movimento em Artaud: a omissão das letras na decomposição da linguagem materna (R, T...); sua retomada numa nova sintaxe ou novos nomes com valor sintático, criadores de uma língua [êTReTé]; enfim, as palavras-sopro, limite assintático para onde tende toda linguagem. [...] Para escrever, talvez seja preciso que a língua materna seja odiosa, mas de tal maneira que uma criação sintática nela trace uma espécie de língua estrangeira e que a linguagem inteira revele seu fora, para além de toda sintaxe. [...] Considerando-se esses critérios, entre todos os que fazem livros com intenções literárias, mesmo entre os loucos, são muito poucos os que podem dizer-se escritores (DELEUZE, 1997, p. 16).

O crítico, ouvindo tudo o que se passava ali, pensou nos estrangeiros na própria língua. Um exemplo bem óbvio estava à sua frente: aquele rapaz magricela e orelhudo que também observava a conversa à distância, entocado no próprio corpo de inseto. Em sua metamorfose, ele exterminara tanto o sentido referencial quanto o metafórico, restando apenas intensidades e "palavras desterritorializadas seguindo sua linha de fuga" (DELEUZE; GUATTARI, 2017, p. 45). Além desse, havia a nossa bela Clarice, que infelizmente não se encontrava ali, estrangeira até numa legião de estrangeiros. Quem seriam esses poucos escritores de que falava Deleuze? Como identificá-los entre tantas vozes e ruídos, entre tantas poses e livros?

CRÍTICO - Com licença, senhores. Desculpem me intrometer, mas eu sou um crítico que desceu ao Hades para descobrir o que é a literatura. Quem são os escritores de quem vocês falam? Poderiam me ajudar? Se eu não levar logo essa resposta ao ditador, nem sei o que me pode acontecer. Ou pior, o que pode acontecer à literatura do meu tempo.

O crítico tomou na cara a gargalhada daqueles mortos galhofeiros, e vocês podem imaginar a qualidade do hálito que empesteou o ambiente. $\mathrm{O}$ visitante estava por entender que ditador e escritor não poderiam coexistir pacificamente. No enfrentamento do rumor indiscernível que chamamos de caos, um impõe o grito, enquanto o outro adensa o silêncio. O primeiro gesto é o de negar o caos, já o segundo, o de reconhecê-lo e procurar uma expressão que possibilite essa convivência, traçar um espaço não só para si como para os que o leem.

BLANCHOT - Os ditadores vêm naturalmente tomar o lugar dos escritores, dos artistas e dos pensadores. Mas, enquanto a fala vazia do comando é o prolongamento assustado e mentiroso do que se prefere ouvir, berrando nas praças públicas, a acolhê-lo e pacificá-lo em si mesmo, por um grande esforço de atenção, o escritor tem uma tarefa muito diferente e também uma responsabilidade muito diversa: a de entrar, mais do que ninguém, numa relação de intimidade com o rumor essencial. É somente a esse preço que ele pode impor-lhe o silêncio, ouvi-lo nesse silêncio e depois exprimi-lo, metamorfoseado (BLANCHOT, 2005, p. 323).

Blanchot concluiu que, se o crítico parasse de servir a ditadores, teria mais chances de conhecer escritores, "como este" - disse dando tapinhas amigáveis nas costas de Mallarmé. De fato, o crítico não lera tanto esse poeta, achava-o meio maçante, impessoal demais.

MALLARMÉ - Apoiar, segundo a página, no branco, que a inaugura sua ingenuidade, a si, esquecida mesmo do título que falaria alto demais: e, quando se alinhou, numa quebra, a menor, disseminada, o acaso vencido palavra por palavra, indefectivelmente o branco volta, ainda há pouco gratuito, certo agora, para concluir que nada ao além e autenticar o silêncio (BLANCHOT, 2010, p. 190).

O crítico entendera só o geral da ideia, e isso porque já tinha lido os ensaios de Blanchot sobre Mallarmé. Compreendeu que o livro, assim como as obras de artes plásticas, dá forma ao silêncio, pois remete ao "nevoeiro da ambiguidade da fala espectral" (BLANCHOT, 2005, p. 323), isto é, ao inacabamento da língua e à ausência de referencialidade mencionados por Deleuze. O publicitário, com seus jogos de palavras mais ou menos sagazes, chamando a atenção das multidões para questões 
que estão na ordem do dia - o que consumir, aonde ir, sobre o que discutir, com quem se relacionar etc. -, é um tipo de ditador, pois faz esquecer daquele rumor impondo uma voz altissonante. E o escritor treinado para atender às expectativas de um público já constituído (um segmento de mercado) é um tipo de publicitário, que por sua vez é um tipo de ditador. Então, quando começava a se desesperar, o crítico lembrou-se das palavras lidas num livro que resenhara recentemente: "O escritor real muitas vezes tem apenas uma ferida cujo nome desconhece, mas que lhe concede silêncio e uma palavra gaga e balbuciante." (PESSANHA, 2018, p. 28).

\section{Performance e ensaio}

São Paulo, Cinemateca Brasileira, Plana Festival Internacional de Publicações, Sala do Absurdo, 25 de março de 2018, 14 horas. $^{3}$ No lado esquerdo do palco, diante de um auditório lotado, vejo Juliano Garcia Pessanha sentado, vestido de modo casual e sóbrio. À sua direita, do ponto de vista do espectador, há um jovem ator também sentado e, ainda mais à direita, três atrizes em pé. O escritor retira de sua bolsa diversas caixas de remédio e as dispõe em parte sobre o chão, em parte sobre uma mesinha. O rapaz ao lado começa a manipular ovos da seguinte forma. Com um prego e um alicate, ele perfura suas extremidades até obter dois pequenos orifícios, apenas o mínimo através do qual consiga passar um fio de espaguete cru. Então, atravessa o macarrão pelos furos, movendo-o para cima e para baixo, até esvaziar toda a clara e a gema num copo. Por fim, com o alicate, aumenta um dos buracos, dando à casca o formato de cuia. Repete com três ovos essa ação, que dura toda a performance.

Em paralelo, as atrizes começam a ler trechos do livro Recusa do não-lugar, primeiro de modo alternado, depois simultaneamente, começando com: "A palavra da arte é coisa de recém-nascido ou de moribundo, de quem não está acostumado com o mundo, mas muito mais tocado pela sua emergência e pela sua desaparição do que envolvido na sua estabilidade." (PESSANHA, 2018, p. 28-29). E seguem por algumas páginas do ensaio "De um lado a outro do entre”, encerrando com: "A palavra é, então, a continuação do arrepio nesse hóspede ligeiro que somos, é a continuação de um canto de assombro e de agradecimento." (PESSANHA, 2018, p. 34). Nos excertos lidos pelas atrizes, explicita-se a metáfora dos ovos, que o ator já vinha narrando gestualmente.

Em seu texto, Pessanha discrimina três tipos de pessoas: o ovo blindado é aquela imune ao exterior, isto é, nenhuma experiência pode tocá-la ou contagiá-la; já o ovo com dois furinhos está não só preenchido como também acompanhado, em outras palavras, é quem possui um mundo interior e também está aberto para o outro; por fim, o ovo rasgado e oco é o indivíduo dessubjetivado que, por não ter interioridade e estar totalmente exposto ao exterior, possibilita uma ressonância melhor do outro, como uma concha acústica. Esse último é a antítese do primeiro e, em geral, decorre dele. Quando o recém-nascido chega ao mundo e, em vez de um aliado leal, encontra um ovo blindado, que lhe nega o toque e não responde a seu canto, ele se torna um ovo-cuia. O taxista sufi, outra metáfora apresentada por Pessanha para reelaborar sua experiência pessoal, é o homem esvaziado que procura se preencher de narrativas alheias. Contudo, as palavras recolhidas de outrem, quando reproduzidas por ele, saem desarticuladas e logo denunciam o vazio que deveriam cobrir, portanto o taxista segue sempre oco.

Da tragédia pessoal, a literatura jorra em abundância, como sugere a epígrafe de Recusa do não lugar, que cita Peter Sloterdijk: "Calamidades humanas, boa oportunidade para o ser!". Assim, Pessanha descreve sua trajetória pessoal em ensaios que misturam testemunho e caso clínico. Quando o homem oco para de falsear a si, após ter encontrado seus semelhantes, como Nietzsche

3 Agradeço a Wagner Antônio, um dos atores que concebeu a performance, pela descrição detalhada desta. 
e os pensadores do exterior, ele começa a valorizar sua capacidade de ressonância, assume-se como uma flauta. Até se convence de que são os homens preenchidos que estão iludidos e assim dignifica o vazio no qual foi atirado. Se não se tornou psicótico nem criminoso, ele corre ainda o risco de se tornar escritor, como ironiza Pessanha.

A literatura, sob esse viés, jamais se compõe de experiências singulares de vida, mas de uma impessoalidade, de um indiscernimento, por isso ela só se realiza no entre, conforme afirma Deleuze: "Algo passa entre os sexos, entre os gêneros ou entre os reinos. O devir está sempre 'entre' ou 'no meio" (DELEUZE, 1997, p. 11). Embora o filósofo empregue aqui a palavra "gênero" num sentido mais biológico (“devir-animal”, “devir-mulher”), podemos entendê-lo também como a forma do texto, o gênero discursivo. A amplitude desse termo é trabalhada de modo bastante consciente por Jacques Derrida na conferência "The law of genre", sobretudo quando ele lança a seguinte provocação: "E se houvesse, alojada no coração da própria lei, uma lei de impureza ou um princípio de contaminação?”, ${ }^{4}$ remetendo à participação dos textos em diversos gêneros sem pertencimento a nenhum propriamente. Desse modo, designações de gênero não fariam parte do corpo do texto - conclusão que poderia aplicar-se também ao corpo humano, segundo a teoria queer. Não por acaso, o autor analisado mais detidamente nessa fala de Derrida é Blanchot, caso exemplar de escrita ensaística, que não estabelece limites entre a literatura e a crítica literária, que se instala no entre.

O gênero ensaístico, tão praticado por Pessanha, seguindo o exemplo de Blanchot, representa bem a noção de "entre" evocada por Deleuze e Derrida, não só por seu hibridismo, mas sobretudo por seu caráter de passagem. No primeiro poema do livro Galáxias, no qual se ressalta a imagem da literatura como viagem, Haroldo de Campos escreve que "um livro ensaia o livro, todo livro é um livro de ensaio de ensaios do livro" (CAMPOS, 2011, p. 13). O ensaio, portanto, sintetizaria a própria experiência literária, o movimento de busca da literatura - mantivemos propositalmente a ambiguidade da preposição, dado que a literatura é tanto sujeito quanto objeto da busca. É por isso que ela tem sempre um caráter metaliterário e, paradoxalmente, sua realização implica o próprio desaparecimento, segundo Blanchot, pois quando se encontra aquilo que era procurado, a busca cessa. Para retomar a expressão que empregamos no início deste texto, trata-se de uma forma que se realiza e se dissolve no entre.

O gênero ensaio não tem a pretensão de se firmar sobre um dado tema ou estilo, mas se compõe em trânsito, na busca por novas relações. Isso não significa que ele não possa ser denso ou complexo, apenas que pretende pôr seus elementos em movimento em vez de os fixar, honrando a metáfora da viagem. Em vez de canonizar procedimentos literários, o ensaio vem para desfazer arranjos; ele não consolida teses nem funda uma tradição, senão a do próprio gesto de propor algo para, logo em seguida, obliterá-lo. Contra a lógica cartesiana, o ensaio exibe uma verve revolucionária, dado que "abala a ilusão desse mundo simples, lógico até em seus fundamentos, uma ilusão que se presta comodamente à defesa do status quo." (ADORNO, 2012, p. 33). Considerando essa descrição, a proximidade com a performance torna-se patente. Ambos são gêneros que evidenciam a transitoriedade do corpo (tanto o humano quanto o corpus literário) e, desse modo, filiam-se à noção de literatura proposta pelo pensamento do exterior: "discurso, portanto, mesmo se ele é, além de qualquer linguagem, silêncio, além de qualquer ser, nada." (FOUCAULT, 2009, p. 222), ou ainda, a busca do poema no gesto autêntico. $^{5}$

Outra semelhança entre ensaio e performance é o protagonismo do indivíduo, que exibe em público as limitações de seu corpo e a variação de seus humores. Em seu discurso para o Prêmio

4 Tradução nossa deste excerto: "What if there were, lodged within the heart of the law ifself, a law of impurity or a principle of contamination?" (DERRIDA, 1992, p. 225).

5 Referir-se a Adorno e Heidegger para defender uma mesma ideia parece incoerente. De fato, aquele desacreditava a pretensão deste de produzir uma filosofia que, remetendo às origens, recuperasse o poema, contudo os dois convergiam na crítica ao pensamento positivista, portanto, observa-se uma breve aliança contra o inimigo comum. 
Europeu de Ensaio de 1982, Jean Starobinski destaca que, no momento em que Michel de Montaigne publicava suas reflexões, ele não só inaugurava um novo gênero de investigação filosófica e literária como afirmava a importância de sua existência singular, enquanto pessoa (PIRES, 2018, p. 1617). No entanto, o gesto de autorretratar-se não tem um fim egocêntrico, pois o autor está ciente da interdependência e de seus deveres cívicos. Como resultado, isto sim, ele lança um olhar para o mundo, dado que, ainda de acordo com Starobinski, esse exercício de observação vem acompanhado de um eco autoconsciente, afinal, a natureza não está alheia a nós, mas se manifesta nos nossos afetos (aquilo que nos afeta). Ensaístas excelentes, como Montaigne, escrevem para "tocar o leitor na carne, arrastá-lo a pensar e sentir mais intensamente.” (PIRES, 2018, p. 22). Também não é esse o efeito que o escritor de literatura e o performer esperam obter? Ou mesmo, abrange qualquer artista: o desejo de produzir afetos, no sentido mais amplo do termo.

$\mathrm{Na}$ parte final daquela performance ocorrida na Sala do Absurdo, cuja descrição deixamos inacabada, Pessanha lê um trecho de outro ensaio seu, "Nascer para dentro no mundo de hoje", no qual expõe suas frustrações com a experiência da negatividade. Ele conta que a deterioração da saúde, a urgência do corpo, despertou-o do delírio messiânico, levando-o a perceber que suas profecias quebradas não provocavam respostas - tornara-se "uma espécie de mestre Eckhart de shopping center" (PESSANHA, 2018, p. 78), pregando para ninguém, sem constituir comunidade com nenhum ser vivente. Diante dessa autoanálise, o taxista sufi dá lugar ao motorista ôntico. Este está atento ao taxímetro e preocupado com as questões financeiras, principalmente com os altos custos de seus tratamentos médicos.

Nasce um novo interesse pelo dentro, mas não mais para forjar uma interioridade que não era a sua, como fizera no passado, e sim para compreender os invólucros que contêm os homens. Os principais aliados nessa transição foram pensadores que exaltam as relações com o outro, a intimidade: o psicanalista inglês Donald Winnicott e o filósofo alemão Peter Sloterdijk. Este, como Pessanha, vem de uma formação heideggeriana, mas também se descola dela por não demonizar a modernidade, inclusive valorizando a criação de espaços artificiais que possibilitem a continuidade da vida. Em vez de dar as costas para os entes na busca do Ser, trata-se de entender a possibilidade de vida neste mundo. Não chega a ser uma ruptura total com Heidegger, mas uma nova proposta de leitura dessa tradição, mais otimista e politicamente engajada.

Desse modo, a iniciativa de Pessanha de despir a "veste do profeta nadificado" (PESSANHA, 2018, p. 164) não necessariamente significa uma rejeição completa daquela visão de literatura defendida pelos pensadores do exterior. Eis outro paradoxo, sintetizado por Pessanha:

Quando alguém lê efetivamente os autores da exterioridade, aliando-se a eles, então nesse próprio gesto encontra-se o desmentido da exterioridade e da perplexidade. Se em alguém ressoa vivamente a leitura de Heidegger e Blanchot ou Kafka e Levinas, então o que acontece nessa leitura já não pode ser soletrado no interior da semântica desses autores, mas apenas numa outra que ouse pensar os encontros fortes e uma poética do encantamento. Como pode um autor do exílio ser casa para alguém? E um autor da solidão tornar-se companhia? E assim é. O encantamento existe quando aquilo que encontramos carrega um pedaço de nós mesmos. E é exatamente essa experiência de alegria, ressonância e expansão de si que está ausente na obra dos devotos da exterioridade. Os autores da exterioridade não explicitam aquilo que eles possibilitam: o encontro. (PESSANHA, 2018, p. 41)

O gesto de ressoar, ainda que consequente do esvaziamento, necessariamente implica a presença do outro, assim, o canto solitário logo se desdobra num dueto ou até num coro. Portanto, mesmo na experiência do exterior (ou especialmente ali), a constituição de comunidades pode ocorrer e, em grande parte, graças à literatura, que cria e doa espaços para esse encontro. A obra de Pessanha ilustra bem isso, ao convocar maciçamente os pensadores que o acompanham, não num gesto de erudição gratuita, mas por reconhecer que são esses aliados que lhe conferem identidade e consistência. 
A literatura tem papel essencial na realização do encontro, tanto com o Ser (HEIDEGGER, 1967) quanto com o ente (SLOTERDIJK, 2016). Mas por que ela chega ao nosso tempo tão invisível, quase irrelevante? De que modo a pilharam e a trancafiaram dentro de instituições imobilizadoras, as academias? Quem elegeu para ela porta-vozes (críticos) tão irrisórios?

\section{Fracasso}

A literatura está em crise, é o que vêm dizendo os acadêmicos profetas já há algum tempo. O fracasso, especifica Pessanha, deve-se à perda do narrar para os especialistas, que não raras vezes têm mais coisas interessantes a dizer e o fazem até melhor. Para ele, agrava-se ainda mais o fracasso quando o escritor tenta imitar o especialista, ao se tornar um "profissional da literatura". De modo geral, o que se observa é o confinamento da literatura a instituições especializadas que afastam o leitor da experiência literária quando reivindicam para si o monopólio das leituras legitimadas - e aqui a universidade pode fazer um mea-culpa. Mas, ao mesmo tempo, são as academias que garantem a sobrevivência de obras, graças ao estudo sistemático destas. Mais um paradoxo para a nossa coleção.

O que dizer então do papel do crítico, que já nasceu nessa posição de perito das letras? Há uma trajetória possível para ele senão a do fracasso? De que serve um crítico que só serve e não critica? Após sua experiência no Hades, o crítico já não tinha mais tanta certeza da própria importância e, para piorar, descobriu que a busca pela literatura não tinha volta, que ele dificilmente conseguiria sair de lá - o fantasma de Eurídice. Contudo, não se desesperou e até viu vantagens naquela estada prolongada. Em profunda crise, não seria qualquer resposta que resolveria seu problema, tampouco uma apressada, por isso, superando o medo de contrapor-se ao ditador, deixou-se ficar, calado. Lamentou-se um pouco no início, é verdade, mas logo se entregou à dança junto com seus companheiros e encontrou alegria nesse gesto.

Curiosamente, ao se calar, os sentidos se aguçaram, foi tateando o que dizer, tudo meio vago, balbucios e ensaios. No silêncio, enfim ouvia certo rumor para o qual nunca atentara, tão distraído que estivera todos esses anos na sua falação narcísica, tantas opiniões compartilhadas em congressos, bancas, artigos, seminários, palestras, aulas, entrevistas, feiras, premiações: eu acho, eu acredito. Talvez o crítico e o escritor não sejam tão diferentes assim um do outro, seja no êxito, seja no fracasso, ambos seguem na mesma busca. O fracasso, se for honesto, é compatível com a postura inerentemente ensaística da literatura, ou melhor, é essencial para ela, pois motiva a continuidade da busca. Já o sucesso ameaça a literatura com a dissolução da palavra.

Em síntese, o Ser heideggeriano, bem como o caos, pode ser interessante para a literatura mais como um horizonte, algo em direção ao qual se caminha sem a distância jamais diminuir, do que como realização, uma vez que o homem parece ser incapaz de lidar com ele sem cair em completo isolamento e delírio. O próprio Foucault (2007), que criticou o desejo racionalista de extirpar a loucura, alerta para o perigo no outro extremo de mistificá-la, afinal, a verdade não se revela na loucura nem na razão, mas no jogo entre ambas, em alguma zona no entre. Se a palavra é "a casa da Verdade do Ser" (HEIDEGGER, 1967, p. 33), disso destaco não o valor de se lançar ao nada no encalço da poesia, mas a importância de se construírem espaços (casas) que tornem as experiências radicais possíveis para o homem, dadas as suas conhecidas limitações. Nem a exposição alucinada ao exterior, nem o fechamento medroso e egoísta no interior, a literatura se faz no entre.

O crítico, que frequentemente se expressa pelo gênero ensaio, não exerce um papel muito diferente daquele que vimos atribuindo ao escritor. Endossam essa afirmação as palavras de Max Bense, num texto publicado originalmente em 1947 e só recentemente traduzido para o português, "O ensaio e sua prosa": 
Ao privilegiar a forma literária do ensaio, o crítico se instala naquele terreno intermediário entre o estado ético, de um lado, e o estado estético-criativo, de outro; não pertence a nenhum dos dois, seu lugar é essa zona intermediária, o que, de um ponto de vista sociológico, significa que ele se situa entre as classes e entre as épocas, que ele encontra seus confrades ali onde se preparam as revoluções (explícitas ou silenciosas), as resistências, as subversões. (BENSE apud PIRES, 2008, p. 119).

A crítica literária está em algum lugar entre uma ciência da arte e a própria arte, por isso Bense (apud PIRES, 2008) conclui que ela possui uma dupla incumbência de ser tanto ética quanto estética. Desse modo, é preciso que o crítico também faça o movimento pendular de retirar-se para encontrar uma forma para suas experiências e de colocar-se no mundo para divulgar a resposta obtida. No entanto, para isso acontecer, precisamos primeiro resgatá-lo do Hades, o que faremos com a ajuda da Literatura e de alguns elementos emprestados de Luciano.

\section{O julgamento}

Aquele Hades começava a parecer familiar ao crítico. Após algum esforço, reconheceu-o dos diálogos luciânicos, mas achava que faltavam ali alguns elementos, por exemplo, um leilão ou um julgamento. Ou ele já estava sendo julgado sem perceber? Sim, era isso. Se estava em crise, segundo a concepção grega de krisis, era óbvio que havia um julgamento em curso, portanto ele tinha direito a um advogado de defesa, alguém que argumentasse pela sua libertação. Imediatamente reivindicou o benefício que lhe cabia, e os demais concordaram, admiradores que eram (ou diziam ser) da democracia ateniense.

Zaratustra anunciou que, para garantir um julgamento justo, convocaria para ser juíza a própria Literatura. Sem demora, buscou uma tabuinha na qual começou a riscar com um estilete algumas letras que o crítico não conseguia identificar, pois essas logo escorriam da superfície encerada e iam se empilhando sobre o chão. A forma que à frente de todos se erguia, ou se esvaziava, já que não se compunha de matéria, e sim dos sulcos abertos na cera, tinha ora zero dimensão como o ponto, ora uma como a linha, ora duas como a página, ora três como o livro, ora quatro, como o rumor orquestrado pelo universo. Cada qual a via, ouvia ou sentia de um jeito. Para alguns, inclusive, a visão era tão obscena que não a toleravam e baixavam a cabeça - no fundo, alguns deles eram velhos puritanos.

Em vez de encontrar uma mulher majestosa como as Musas que conhecia de livros e museus, o crítico foi surpreendido por um furacão. Que Hilda, que nada. O esperançoso senhor precisava abdicar de uma vez por todas do fetiche por imagens femininas, não se tratava de uma femme fatale, mas de um tornado literal, o fenômeno meteorológico. Nem preciso dizer que esse era cinza-chumbo e violento, pois não existem furações gentis sequer nos contos infantis - Dorothy que o diga.

A coluna de ar, que chegava a 500 mil quilômetros, puxou o crítico tão alto que ele quase bateu a cabeça na Lua, sorte que se abaixou a tempo. No início da subida, as lufadas o chicoteavam com milhões de gritos e gemidos, chegou a sentir seus tímpanos estourarem, mas era só efeito do pavor sobre sua imaginação. Ao ultrapassar a atmosfera, esse problema se resolveu. Pairava um silêncio absoluto como nunca experimentara antes, contudo logo surgiu outro percalço, a falta de ar. Seus pulmões, desacostumados a lidar com o vácuo, viraram duas uvas passas, o que o fez lembrar-se da proximidade do Natal. Tomado de nostalgia, nem sabia em relação a que, o crítico começou a chorar, mas, como a temperatura no espaço era muito baixa, as lágrimas saíam como pedras de gelo, e isso era especialmente incômodo. $\mathrm{O}$ tornado Literatura o transtornava.

Tudo isso aconteceu no plano ficcional, uma experiência caósmica gerada nas entranhas da própria mãe da ficção, a Literatura. Eu, a autora deste relato, asseguro-lhes que é tudo inventado, pois fui 
eu mesma quem o inventou, com a ajuda de outros amigos da mentira com quem tenho dialogado. Conto-lhes aquilo que não poderia acontecer, e isso admito desde já para que ninguém venha se queixar de falta de honestidade da minha parte. Se algum leitor tomar o feito por mim como fato, será por sua conta e risco.

Ainda assim, vocês insistem para que eu conclua essa história absurda? Por que preferem as mentiras inventadas por mim àquelas criadas por sua própria imaginação? Já entendi. Pelo aspecto pálido e flácido de vocês, suponho que tenham frequentado muitos banquetes, acostumaram-se a ser tão somente servidos. Da imobilidade física, vai-se à moral, à social e até à intelectual. Pois bem, gulosos, tomem mais histórias suculentas, porém só na próxima noite, pois a manhã já desponta.

\section{Nota explicativa 2}

Além do diálogo cômico, que lhe possibilitou tantas visitas ao Hades para investigar sobre o bemviver (as escolhas filosóficas) ou simplesmente para expor figurões, Luciano escreveu textos em prosa nos quais refletiu sobre a escrita da história e a da ficção. Nesses, inclusive, deu um passo adiante em relação à poética de Aristóteles, pois defendeu a absoluta liberdade do discurso ficcional, status que, no geral, mantém-se até hoje. Se o historiador trata do que aconteceu (o verdadeiro) e o poeta do que poderia acontecer (o verossímil), o ficcionista atinge um grau de liberdade ainda maior do que o deste último, uma vez que trata até do que não poderia acontecer, conforme ressalta Jacyntho Lins Brandão. Segundo a hipótese desenvolvida por esse pesquisador em sua tese de doutorado, "o que faz da obra de Luciano um objeto permanente de interesse é a possibilidade de acompanhar como se processa nela uma autêntica "descoberta da ficção", que consequentemente define um estatuto não só para o discurso, como também para o escritor e o leitor.” (BRANDÃO, 2001, p. 27).

Nesta releitura paródica da obra de Luciano, procurei refletir sobre o estatuto da literatura a partir de uma vertente teórica bastante presente nas discussões dentro da universidade brasileira, o pensamento do exterior. Eu própria quis dar meu passo além ao acrescentar também nesse jogo a figura do crítico, afinal, ele não ocupa uma posição tão cômoda como pode parecer para alguns nem está alheio à relação entre escritor e leitor. Do mesmo modo que esses dois últimos, também o crítico é arrebatado pela experiência literária, que se manifesta das mais diversas e perturbadoras formas. Tanto autor quanto crítico - e ainda o leitor, se ele quiser - precisam resistir ao narcisismo para poder dar uma resposta à sociedade. Só assim terão condições de defender a existência da literatura, sobretudo quando a sociedade permite, ou até deseja, a ascensão de ditadores.

\section{Na noite seguinte}

Quando o tornado cuspiu o crítico, ele voou através da janela de seu gabinete, que por sorte estava aberta, e caiu precisamente sentado à sua mesa de trabalho. Diante de si, o computador ligado exibia uma página em branco. Olhou o calendário e o relógio no canto da tela, as 24 horas cedidas pelo ditador haviam recém se esgotado. Nem teve tempo para se alegrar pelo veredito favorável da Literatura, precisava agir rápido. O que ele tinha a dizer sobre aquela experiência? Ouve batidas firmes à porta. 


\section{Referências}

ADORNO, Theodor. O ensaio como forma. In: ADORNO, Theodor. Notas de literatura I. São Paulo: Duas Cidades; Editora 34, 2012.

ARTAUD, Antonin. A perda de si: cartas de Antonin Artaud. Rio de Janeiro: Rocco, 2017.

BLANCHOT, Maurice. O livro por vir. São Paulo: Martins Fontes, 2005.

BRANDÃO, Jacyntho Lins. A poética do hipocentauro: literatura, sociedade e discurso ficcional em Luciano de Samósata. Belo Horizonte: Editora UFMG, 2001.

CAMPOS, Haroldo de. Galáxias. São Paulo: Editora 34, 2011.

DELEUZE, Gilles. A literatura e a vida. In: DELEUZE, Gilles. Crítica e clínica. São Paulo: Ed. 34, 1997.

DELEUZE, Gilles; GUATTARI, Félix. Kafka: por uma literatura menor. Belo Horizonte: Autêntica, 2017.

DERRIDA, Jacques. The Law of Genre. In: DERRIDA, Jacques; ATTRIDGE, Derek. Acts of literature. New York; London: Routledge, 1992.

FOUCAULT, Michel. História da loucura: na Idade Clássica. São Paulo: Perspectiva, 2007.

FOUCAULT, Michel. O pensamento do exterior. In: FOUCAULT, Michel. Estética: literatura e pintura, música e cinema. Rio de Janeiro: Forense Universitária, 2009.

GOMBROWICZ, Witold. Ferdydurke. São Paulo: Companhia das Letras, 2006.

HEIDEGGER, Martin. Sobre o humanismo. Rio de Janeiro: Tempo Brasileiro, 1967.

MAIOLINO, Anna Maria, O herói. Disponível em: <https://masp.org.br/acervo/obra/o-heroi>. Acesso em: 29 jan. 2019.

MALLARMÉ, Stéphane. Divagações. Florianópolis: Editora da UFSC, 2010.

PEDROSA, Celia et al. (Orgs.). Indicionário do contemporâneo. Belo Horizonte: Editora UFMG, 2018.

PESSANHA, Juliano Garcia. Recusa do não-lugar. São Paulo: Ubu, 2018.

PIRES, Paulo Roberto (Org.). Doze ensaios sobre o ensaio. São Paulo: IMS, 2018.

RANCIÈrE, Jacques. A partilha do sensível. São Paulo: Ed. 34, 2005.

SAMÓSATA, Luciano de. Luciano [III]. Coimbra: IUC, 2012.

SAMÓSATA, Luciano de. Luciano [VI]. Coimbra: IUC, 2013.

SLOTERDIJK, Peter. Esferas I: Bolhas. Tradução de José Oscar de Almeida Marques. São Paulo: Estação Liberdade, 2016.

SÜSSEKIND, Flora. Objetos textuais não identificados. In: O Globo, 2013. Disponível em: $<$ https://blogs.oglobo.globo.com/prosa/post/objetos-verbais-nao-identificados-um-ensaio-de-florasussekind-510390.html>. Acesso em: 12 nov. 2018. 